\title{
PENERAPAN MODEL PEMBELAJARAN AMORA TERHADAP KEMAMPUAN BERPIKIR KRITIS SISWA
}

\author{
Novianti $^{1}$, Siti Khaulah ${ }^{2}$ \\ ${ }^{1.2}$ Universitas Almuslim, jalan Tengku Abdurrahman Matangglumpangdua Bireuen, 24261, Indonesia \\ Email: novianti.idr@gmail.com \\ Email: sitikh800@gmail.com
}

\begin{abstract}
Abstrak
Rendahnya kemampuan berpikir kritis siswa salah satu permasalahan yang menuntut seorang guru untuk menciptakan dan menerapkan model pembelajaran matematika. Salah satu model pembelajaran yang dapat meningkatkan kemampuan berpikir kritis siswa adalah model AMORA. Penelitian ini bertujuan untuk mengetahui kemampuan berpikir kritis siswa melalui model pembelajaran AMORA pada materi Penyajian Data di kelas VII SMP N 3 Bireuen lebih baik digunakan daripada pembelajaran konvensional. Penelitian ini merupakan penelitian kuantitatif dengan rancangan penelitian eksperimen semu. Populasi penelitian ini adalah seluruh siswa VII SMP N 3 Bireuen yang terdiri dari 4 kelas. Kemudian sampel penelitian ini dipilih secara Purposive Sampling yaitu kelas VII/3 sebagai kelas eksperimen dengan menggunakan model pembelajaran AMORA dan kelas VII/4 sebagai kelas Kontrol dengan menggunakan model pembelajaran konvensional. Instrument yang digunakan adalah tes kemampuan berpikir kritis siswa yaitu tes awal (pre-test) dan test akhir (post-test) dalam bentuk uraian masing-masing 4 butir soal. Soal yang diberikan pada kedua kelas adalah sama yaitu masalah penyajian data. Analisis data dilakukan dengan menggunakan uji-t pada taraf signifikan $\alpha=0,05$, hasil pengujian hipotesis dengan menggunakan uji t independent sample test diperoleh nilai nilai sig. (2 Tailed) yaitu 0.000 . Hal ini menunjukkan bahwa nilai sig. (2 Tailed) $<0,05$ atau lebih kecil pada taraf nyata $5 \%$ maka $\mathrm{H}_{0}$ ditolak. Hasil penelitian ini menunjukkan bahwa kemampuan berpikir kritis yang diajarkan dengan model AMORA lebih baik dari pada yang diajarkan dengan pembelajaran konvensional pada materi Penyajian Data di kelas VII SMPN 3 Bireuen.
\end{abstract}

Kata Kunci: AMORA, Kemampuan Berfifkir Kritis

\begin{abstract}
The low ability of students to think critically is one of the problems that requires a teacher to create and apply a mathematics learning model. One of the learning models that can improve students' critical thinking skills is the AMORA model. This study aims to see students' critical thinking skills through the AMORA learning model in data presentation material in class VII SMP N 3 Bireuen which is better used for conventional learning. This research is a quantitative research with experimental experimental research. The population of this research was all students VII SMP N 3 Bireuen which consisted of 4 classes. Then the research sample was selected by purposive sampling, namely class VII / 3 as an experimental class using the AMORA learning model and class VII / 4 as a control class using conventional learning models. The instrument used was a test of students' critical thinking skills, namely a pre-test and a post-test in the form of a description of each of the 4 questions. The questions given to both classes are the same, namely the problem of presenting the data. Data analysis was performed using t-test at a significant level $\alpha=0.05$, the test results using the $\mathrm{t}$ test independent sample test obtained the value of sig. ( 2 Tailed), namely 0.000 . This shows that the sig. ( 2 Tailed) $<0.05$ or less at the $5 \%$ real level, then $\mathrm{H} 0$ is rejected. The results showed that the ability to think critically with the AMORA model was better than those who taught using conventional learning on the presentation of data in class VII SMPN 3 Bireuen.
\end{abstract}

Keywords: AMORA, Critical Thinking Skills 


\section{PENDAHULUAN}

Pada pembelajaran matematika konsep dasar sangatlah berpengaruh bagi siswa, berdasarkan hasil wawancara dengan guru bidang studi SMP N 3 Bireuen, konsep dasar yang dimiliki oleh siswa juga harus ada kesinambungan antara konsep yang telah dipelajari terdahulu dengan konsep yang akan dipelajari. Hal ini disebabkan bahwa dalam belajar matematika meskipun kita telah membuat semua konsep itu menjadi baru dalam pikiran kita sendiri, kita hanya bisa melakukan semua ini dengan menggunakan konsep yang kita capai sebelumnya. Dalam mempelajari dan memahami matematika salah satu kemampuan yang harus dimilik siswa adalah kemampuan berpikir kritis siswa yag disesuaikan dengan model pembelajaran AMORA. Menurut (Novianti dan Khaulah, 2020) Banyak faktor yang mempengaruhi siswa beranggapan matematika sult dipelajari salah satunya karena kurangnya kemampuan siswa dalam berpikr kritis. Matematika diberikan sejak dini disekolah untuk membekali anak dengan kemampuan berpikir logis, analitis, sistematis, kritis,, kreatif, serta kemampuan bekerja sama. Berpikir kritis adalah interpretas dan evaluasi yang terampil serta aktif terhadap observasi dan komunikasi, nformasi dan argumentasi (Fisher, 2009)

Indikator keterampilan berpikir kritis meliputi: 1) mengidentifkasi elemen-elemen dalam kasus yang dipikirkan khususnya alasan dan kesimpulan; 2) mengidentifikasi dan mengevaluasi asumsiasumsi; 3) mengklarifikasi dan menginterpretasi pernyataan-pernyataan dan gagasan-gagasan; 4) menilai ekseptabilitas khususnya krediabilitas, mengevaluasi argument-argumen yang beragam jenis, menganalisis, mengevaluasi dan membuat keputusan, menarik nfeensi-inferensi, menghasilkan argumen (Fisher, 2009). Sedangkan menurut Ennis (1985) indikator berpikir kritis diklasfikasikan menjadi lima yaitu: 1) memberikan penjelasan sederhana (elementary clarification); 2) membangun keterampilan dasar (basic support); 3) menyimpulkan (interfance); 4) membuat penjelasan lebih lanjut (advance clarification); 5) serta strategy dan taktik ( strategi and tactics) .

Rendahnya pemahaman siswa dalam mengaitkan hubungan konsep matematika dengan topik lain juga disebabkan guru masih cenderung aktif menggunakan model pembelajaran konvensional. Akibatkan ketidaksesuaian model pembelajaran dengan materi yang diajarkan mengakibatkan siswa tidak mampu menghubungkan konsep yang satu dengan yang lainnya. Oleh karena itu perlu dilakukannya perubahan teknik pembelajaran sehingga para siswa dapat secara mandiri dalam proses pembelajaran di sekolah. Model pembelajaran yang ditawarkan adalah Model Pembelajaran AMORA.

Menurut Iriawan (2019) menjelaskan bahwa model pembelajaran matematika amora merupakan model pembelajaran matematika yang diturunkan dari prinsip-prinsip pembelajaran pada pendekatan Sistem Among Ki Hadjar Dewantara yang terdiri dari prinsip kodrat alam dan prinsip kemerdekaan. Langkah-langkah pembelajaran Amora terdiri dari 4 tahapan yaitu: (1) Amati, pada tahap ini merupakan tahap awal pembelajaran untuk memperkuat materi pembelajaran yang telah dipelajari sebelumnya sebagai materi prasyarat melalui proses pembelajaran yang dilakukaan dengan mengkondiskan sswa secara klasikal untuk terlibat dan/atau mengalami kembali situasi didakts yang nyata dan dekat dengan kehidupan siswa terkait materi pembelajaran yang telah dipelajari sebelumnya sebagai materi prasyarat; (2) Momong dan Ngemong, pada tahap ini pembelajaran dilakukan dengan setiap siswa secara mandiri melakukan kembali atau mengulangi langkah kerja seorang ilmuwanmelalui aktivitas inkuiri terbimbing dalam menemukan kembali pengetahuan berupa proposisi matematis yang telah terbuktti kebenarannya terdiri atas fakta, konsep, prinsip, dan prosedur matematis tertentu; (3) Ngrasake, pada tahap ini merupakan tahap tahap lanjut pembelajaran untuk mengapresiasi proses dan hasil belajar matematika siswa dalam melakukan repersonalisasi matematis, Pembelajaran dilakukan dengan guru memberikan apresiasi kepada siswa secara individual dalam bentuk kata-kata motivasi, sanjungan postif dan membangun, penghargaan dan bentuk apresiasi individual lainnya; (4) Among, tahap ini merupakan tahap akhir pembelajaran untuk memperkuat pemahaman matematika siswa yang dilakukan dengan berbagai proses dan hasil repersonalisasi 
matematis bersama siswa lainnya, kemudian guru menguatkan hasil dan proses repersonalisasi matematis siswa melalui metode ceramah, demonstrasi, simulasi atau lainnya (Iriawan, 2019).

Kemampuan Berpikir Kritis siswa sangat diperlukan dengan memperhatikan indikator-indikator yang harus dicapai dalam pelaksanaan pembelajarannya. Berdasarkan paparan diatas, maka tujuan penelitian ini adalah untuk membandingkan pembelajaran menggunakan model pembelajaran AMORA dengan pembelajaran Konvensional terhadap kemampuan berpikir Kritis pada materi Penyajian Data.

\section{METODE PENELITIAN}

\section{Rancangan Penelitian}

Jenis penelitian ini adalah menggunakan pendekatan kuantitatif Adapun jenis penelitian yang digunakan dalam penelitian ini adalah jenis penelitian eksperimen semu. Menurut Sugiyono (2011:109) penelitian eksperimen merupakan penelitian yang digunakan untuk mencari pengaruh perlakuan tertentu terhadap yang lain dalam kondisi yang terkendalikan.

Menurut Sugiono (2011:119)" populasi adalah wilayah generalisasi yang terdiri atas: objek atau subjek yang mempunyai kualitas dan kreativitas tertentu diterapkan oleh peneliti untuk dipelajari dan kemudian ditarik kesimpulannya". Subjek dalam populasi penelitian ini adalah seluruh siswa kelas VII SMP N 3 Bireuen yang berjumlah 5 kelas. Sedangkan sampel adalah sebagian atau wakil populasi yang diteliti. Dalam penelitian ini, sampel diambil secara purposive sampling (sampling pertimbangan) yaitu dua kelas, kelas eksperimen dan kelas kontrol. Tes yang digunakan adalah tes awal (pre-test) dan tes akhir (post-test) yang merupakan tes untuk melihat sejauh mana kemampuan berpikir kritis siswa. Jenis soal yang digunakan pada pre-test dan post-test adalah jenis soal uraian.

Dalam penelitian ini digunakan dua kelas yaitu kelas eksperimen dan kelas kontrol, kelas eksperimen dalam penelitian ini adalah kelas yang mendapat perlakuan dimana pada kelas tersebut diajarkan dengan pembelajaran AMORA, sedangkan pembelajaran Penyajian Data untuk kelas kontrol diajarkan dengan model pembelajaran konvensional. Dengan demikian, desain eksperimen dalam penelitian ini menggunakan Nonequivalent Control Group Design Menurut Sugiyono (2011:113), adapun tabel desain penelitian adalah sebagai berikut :

Tabel 1. Rancangan penelitian

\begin{tabular}{lll}
\hline $\mathrm{O}_{1}$ & $X_{1}$ & $\mathrm{O}_{2}$ \\
\hline $\mathrm{O}_{3}$ & $X_{2}$ & $\mathrm{O}_{4}$ \\
\hline
\end{tabular}

Keterangan:

$\mathrm{O}_{1}:$ Pre-test untuk kelas AMORA

$\mathrm{O}_{3}$ : Pre-test untuk kelas konvensional

$\mathrm{X}_{1}$ : Perlakuan model pembelajaran AMORA

$\mathrm{X}_{2}$ : Perlakuan model pembelajaran konvensional

$\mathrm{O}_{2}:$ Post-test untuk kelas AMORA

$\mathrm{O}_{4}$ : Post-test untuk kelas konvensional

Tes yang digunakan adalah tes awal (pre-test) dan tes akhir (post-test) yang merupakan tes untuk melihat sejauh mana kemampuan berpikir kritis siswa. Jenis soal yang digunakan pada pre-test dan post-test adalah jenis soal uraian.

Pre-test diberikan untuk mengukur kemampuan awal siswa sebelum membentuk kelompok secara heterogen. Sedangkan post-test digunakan untuk mengetahui sejauh mana kemampuan berpikir kritis siswa setelah menerima masing-masing perlakuan. 


\begin{abstract}
$\mathrm{H}_{0}: \mu_{1}=\mu_{2}$ : Penerapan kemampuan berpikir kritis siswa yang diajarkan melalui model pembelajaran AMORA sama baik dengan pembelajaran konvesional pada materi Penyajian Data di kelas VII SMPN 3 Bireuen.

$\mathrm{H}_{\mathrm{a}}: \mu_{1}>\mu_{2}$ : Penerapan kemampuan berpikir kritis siswa yang diajarkan melalui model pembelajaran AMORA lebih baik daripada model pembelajaran konvesional pada materi Penyajian Data di kelas VII SMPN 3 Bireuen.
\end{abstract}

\title{
HASIL PENELITIAN DAN PEMBAHASAN
}

\section{Analisis Data Tes Awal (pre-test)}

Penelitian ini bertujuan untuk mengetahui kemampuan berpikir kritis siswa melalui model pembelajaran AMORA lebih baik dari pada kemampuan berpikir kritis siswa melalui model pembelajaran konvensional pada materi program linear. Berdasarkan hasil analisis data tes awal untuk kelas eksperimen dan control dapat dilihat pada tabel 3 dibawah ini berdasarkan nilai variasi dan simpangan baku:

Tabel 3. Rekapitulasi Hasil Tes Awal

\begin{tabular}{cccc}
\hline \multirow{2}{*}{ Kelas } & $\begin{array}{c}\text { Nilai rata-rata } \\
(\overline{\boldsymbol{x}})\end{array}$ & $\begin{array}{c}\text { Varians } \\
\left(\boldsymbol{s}^{\mathbf{2}}\right)\end{array}$ & $\begin{array}{c}\text { Simpangan baku } \\
(\text { SB })\end{array}$ \\
\hline Eksperimen & 36,62 & 105,84 & 10,32 \\
Kontrol & 34,21 & 86,88 & 9,32 \\
\hline
\end{tabular}

Setelah data pre-test kelas eksperimen dan kelas kontrol selesai disusun kedalam tabel distribusi frekuensi, maka langkah selanjutnya adalah menguji persamaan rata-rata data pre-test dengan menggunakan uji-t. Sebelum data dianalisis dengan uji-t, maka terlebih dahulu data masingmasing kelas harus memenuhi syarat Normalitas dan Homogenitas varians. Uji normalitas bertujuan untuk mengetahui apakah data dari masing-masing kelompok berdistribusi normal atau tidak. Adapun hasil rekapitulasi dari pengujian normalitas dapat dilihat pada tabel 4.

Tabel 4. Hasil Pengujian Normalitas Tes Awal

\begin{tabular}{|l|r|r|r|r|r|r|}
\hline \multirow{2}{*}{} & \multicolumn{3}{|c|}{ Kolmogorov-Smirnov ${ }^{\mathrm{a}}$} & \multicolumn{3}{c|}{ Shapiro-Wilk } \\
\cline { 2 - 7 } & Statistic & \multicolumn{1}{c|}{$\mathrm{df}$} & \multicolumn{1}{c|}{ Sig. } & Statistic & \multicolumn{1}{c|}{ df } & \multicolumn{1}{c|}{ Sig. } \\
\hline Eksperimen & .143 & 32 & .094 & .937 & 32 & .061 \\
Kontrol & .151 & 32 & .063 & .933 & 32 & .049 \\
\hline
\end{tabular}

Berdasarkan tabel 4 diatas, dapat disimpulkan nilai sig. dari kelas eksperimen 0,094 dan kelas control 0,063 dimana kedua nilai tersebut lebih besar dari derajat kebebasan 5\%, yang dapat disimpulkan bahwa data tesebut berdistribusi normal. Adapun untuk menguji homogenitas dapat dilihat pada tabel dibawah ini. Adapun hasil rekapitulasi dari pengujian homogenitas dapat dilihat pada Tabel 5 .

Tabel 5. Hasil Pengujian Homogenitas Tes Awal

\begin{tabular}{|c|c|c|c|}
\hline $\begin{array}{l}\text { Levene } \\
\text { Statistic }\end{array}$ & df1 & df 2 & Sig. \\
\hline .740 & 1 & 62 & .393 \\
\hline
\end{tabular}


Berdasarkan tabel 5 output "test homogenity of variance" diatas diketahui nilai signifikan (sig.) 0,393 lebih besar dari 0,05. Maka dapat disimpulkan bahwa varians data nilai pengjian homogenitas untuk tes awal adalah homogen.

\section{Analisis Data Tes Akhir (post-test)}

Sebelum data dianalisis lebih lanjut, data yang telah dikumpulkan disusun ke dalam daftar distribusi frekuensi terlebih dahulu.

Tabel 6. Rekapitulasi Hasil Tes Akhir

\begin{tabular}{cccc}
\hline Kelas & Nilai rata-rata $(\bar{x})$ & Varians $\left(\mathbf{S}^{\mathbf{2}}\right)$ & Simpangan baku (SB) \\
\hline Eksperimen & 76,5 & 130,38 & 11,41 \\
Kontrol & 61,84 & 110,20 & 10,49 \\
\hline
\end{tabular}

Berdasarkan tabel 6 diatas, Untuk nilai tes akhir, diperoleh nilai rata-rata untuk kelas eksperimen adalah 76,5 sedangkan kelas control diperoleh 61,84. Untuk nilai varians kelas eksperimen diperoleh 130,38 dan kelas control 110,20. Sedangkan untuk Simpangan Baku untuk kelas eksperimen diperoleh 11,41 dan kelas control 10,49. Tahap selanjutnya yang dilakukan adalah mencari uji normalitas seperti paada tabel 7.

Tabel 7. Hasil Pengujian Normalitas Tes Akhir

\begin{tabular}{|l|r|r|r|r|r|r|}
\hline & \multicolumn{3}{|c|}{ Kolmogorov-Smirnov ${ }^{\mathrm{a}}$} & \multicolumn{3}{c|}{ Shapiro-Wilk } \\
\cline { 2 - 7 } & Statistic & \multicolumn{1}{c|}{ df } & \multicolumn{1}{c|}{ Sig. } & Statistic & \multicolumn{1}{c|}{ df } & \multicolumn{1}{c|}{ Sig. } \\
\hline Eksperimen & .159 & 32 & .039 & .934 & 32 & .051 \\
Kontrol & .149 & 32 & .069 & .936 & 32 & .057 \\
\hline
\end{tabular}

Berdasarkan tabel 7 diatas, dapat disimpulkan nilai sig. dari kelas eksperimen 0,039 dan kelas control 0,069 dimana kedua nilai tersebut lebih besar dari derajat kebebasan 5\%, yang dapat disimpulkan bahwa data tesebut berdistribusi normal. Adapun untuk menguji homogenitas dapat dilihat pada tabel dibawah ini. Hasil rekapitulasi dari pengujian homogenitas dapat dilihat pada Tabel 5 .

Tabel 8. Hasil Pengujian Homogenitas Tes Akhir

\begin{tabular}{|c|c|c|c|}
\hline Levene Statistic & df1 & df 2 & Sig. \\
\hline .245 & 1 & 62 & .623 \\
\hline
\end{tabular}

Berdasarkan tabel 8 output" test homogenity of variance" diatas diketahui nilai signifikan (sig.) 0,623 lebih besar dari 0,05. Maka dapat disimpulkan bahwa varians data nilai pengjian homogenitas untuk tes awal adalah homogen. Langkah selanjutnya yang dilakukan adalah untuk mengetahui apakah pembelajaran dengan menggunakan model AMORA lebih baik dari pada konvemsional, maka harus dianalisis dengan uji-t.

\section{Uji Hipotesis Data Post-Test}

Pengujian hipotesis dalam penelitian ini di uji menggunakan uji- $t$ pada taraf signifikan $\alpha=0,05$. Maka teknik uji- $t$ yang digunakan adalah uji $t$ satu pihak yaitu uji pihak kanan, sehingga pengujiannya dilakukan berdasarkan hipotesis: 
$\mathrm{H}_{\mathrm{o}}: \mu_{1}=\mu_{2} \quad$ : Penerapan kemampuan kritis siswa yang diajarkan melalui model pembelajaran AMORA sama dengan yang diajarkan dengan pembelajaran konvensional pada materi penyajian data dikelas VII SMPN 3 Bireuen.

$\mathrm{H}_{\mathrm{a}}: \mu_{1}>\mu_{2}$ : Penerapan kemampuan kritis siswa yang diajarkan melalui model pembelajaran AMORA lebih baik daripada siswa yang diajarkan dengan pembelajaran konvensional pada materi penyajian data dikelas VII SMPN 3 Bireuen

Tabel 9. Hasil Uji Hipotesis

\begin{tabular}{|c|c|c|c|c|c|c|c|c|c|c|}
\hline & \multicolumn{2}{|c|}{$\begin{array}{l}\text { Levene's } \\
\text { Test for } \\
\text { Equality } \\
\text { of } \\
\text { Variances }\end{array}$} & \multicolumn{7}{|c|}{ t-test for Equality of Means } \\
\hline & & \multirow[b]{2}{*}{$\mathrm{F}$} & \multirow[b]{2}{*}{ Sig. } & \multirow[b]{2}{*}{$\mathrm{t}$} & \multirow[b]{2}{*}{ Df } & \multirow[b]{2}{*}{$\begin{array}{l}\text { Sig. (2- } \\
\text { tailed) }\end{array}$} & \multirow[b]{2}{*}{$\begin{array}{c}\text { Mean } \\
\text { Differenc } \\
\mathrm{e}\end{array}$} & \multirow[b]{2}{*}{$\begin{array}{l}\text { Std. Error } \\
\text { Difference }\end{array}$} & \multicolumn{2}{|c|}{$\begin{array}{l}\text { 95\% Confidence } \\
\text { Interval of the } \\
\text { Difference }\end{array}$} \\
\hline & & & & & & & & & Lower & Upper \\
\hline Nilai & $\begin{array}{l}\text { Equal } \\
\text { variances } \\
\text { assumed }\end{array}$ & .245 & .623 & 3.98 & 62 & .000 & 12.25000 & 3.07393 & 6.10531 & 18.39469 \\
\hline & $\begin{array}{l}\text { Equal } \\
\text { variances } \\
\text { not } \\
\text { assumed }\end{array}$ & & & 3.98 & 61.97 & .000 & 12.25000 & 3.07393 & 6.10525 & 18.39475 \\
\hline
\end{tabular}

Pengujian hipotesis menggunakan Independent Samples Test, berdasarkan hasil perhitungan diatas diperoleh nilai nilai sig. ( 2 Tailed) yaitu 0.000 . Hal ini menunjukkan bahwa nilai sig. (2 Tailed) $<0,05$ atau lebih kecil pada taraf nyata $5 \%$ maka $\mathrm{H}_{0}$ ditolak, sehingga $\mathrm{H}_{\mathrm{a}}$ diterima. yang berarti bawa hasil belajar siswa dengan menerapkan metode pembelajaran sistem AMORA lebih baik dari hasil belajar pada pembelajaran konvensional. Maka dapat disimpulkan bahwa terdapat persamaan rata-rata kemampuan akhir siswa antara kelompok eksperimen dengan kelas kontrol.Sehingga $\mathrm{H}_{0}$ ditolak dan $\mathrm{H}_{\mathrm{a}}$ diterima. Maka dapat disimpulkan bahwa penerapan kemampuan kritis siswa yang diajarkan melalui model pembelajaran AMORA lebih baik daripada siswa yang diajarkan dengan pembelajaran konvensional pada materi penyajian data di kelas VII SMPN 3 Bireuen.

\section{KESIMPULAN}

Berdasarkan hasil analisis dan pembahasan dalam penelitian ini mengenai kemampuan berpikir kritis siswa, diperoleh hasil perhitungan diatas diperoleh nilai nilai sig. (2 Tailed) yaitu 0.000. Hal ini menunjukkan bahwa nilai sig. ( 2 Tailed) $<0,05$ atau lebih kecil pada taraf nyata $5 \%$ maka $\mathrm{H}_{0}$ ditolak, sehingga $\mathrm{H}_{\mathrm{a}}$ diterima. Maka dapat disimpulkan bahwa: Penerapan model pembelajaran AMORA terhadap kemampuan berpikir kritis siswa lebih baik daripada model pembelajaran konvensional pada materi Penyajian Data dikelas VII SMP N 3 Bireuen.

\section{REFERENCES}

Arifin, Zainal. (2011). Evaluasi Instruksional Prinsip-Teknik-Prosedur. Bandung: CV Remadja Karya 
Ennis, R.H. (1985). A Logical Basic for Measuring Critical Thinking Skills. Educational Leadership, 43(2):44-48

Fisher, A. (2009). Berpikir Kritis Sebuah Pengantar. Jakarta: Erlangga.

Iriawan, S, B. (2019). Pengembangan Model Pembelajaran Matematika Berbasis Sistem Among Ki Hadjar Dewantara untuk Meningkatkan Kemampuan Berpikir Kritis, Kemandirian Belajar, dan Kebiasaan Berpikir Matematis Siswa Sekolah Dasar. (Disertasi). Sekolah Pascasarjana, Universitas Pendidikan Indonesia, Bandung. [Tidak Dipublikasikan]

Riyadi, Usman. (2008). Memahami Berpikir kritis. Skripsi. Semarang: Universitas Negeri Semarang. http://lib.unnes.ac.id/16837/1/4001506030.pdf.

S. Khaulah and N. Novianti, "Penerapan Strategi Pembelajaran Numbered Head Together (NHT) Untuk Meningkatkan Kemampuan Berpikir Kritis Siswa Pada Materi Trigonometri Di Kelas X Sma Negeri 1 Kuala" Jurnak Edukasi Matematika dan Sains, 2019. http://jfkip.umuslim.ac.id/index.php/jemas/article/viewFile/519/383

Sugiyono. (2011). Metode Penelitian Kuantitatif Kualitatif dan R\&D. Bandung: Alfabeta. 